\title{
The New Life: Construction sites and mine fields
}

FIZ Advocacy and Support for Migrant Women and Victims of Trafficking

Please cite this article as: FIZ Advocacy and Support for Migrant Women and Victims of Trafficking, 'The New Life: Construction sites and mine fields', Anti-Trafficking Review, issue 10, 2018, pp. 156-159, www.antitraffickingreview.org

Interview with Sara Donath, counsellor at FIZ Fachstelle Frauenhandel und Frauenmigration (FIZ Advocacy and Support for Migrant Women and Victims of Trafficking, Switzerland). ${ }^{1}$

Sara Donath has counselled hundreds of survivors of trafficking and accompanied them into their new lives. We asked Sara about the experiences of these women after having experienced exploitation and violence.

FIZ: The survivors you and your colleagues counsel must build a new life. What are the biggest challenges for them?

Sara: Survivors of trafficking must begin a new life-but of course they don't start from zero. They carry along baggage from their previous lives. Exploitation and violence leave their marks: fear, panic attacks, sometimes a tendency to hurt oneself, mistrust of other people and so on. Also, before they were trafficked, many women had experienced abuse, deprivation and traumatisation. Some of them to such an extent that they are very ambivalent. They want to survive but at the same time are very self-destructive. It is in this situation that survivors have to build their future. They must tend to many 'construction sites' in their lives simultaneously. This is a lot of work. And all along they must walk through 'mine fields'.

FIZ: What do you mean by 'mine fields'?

Sara: Survivors who decide to testify against their perpetrators feel strong at first. They fight back and this gives them energy. But it also has side effects. At the beginning of a lawsuit, the victim will be questioned many times and will have to explain in detail what happened to her. She cannot leave it behind and has to re-live it over and over. And then the sentence often does not look at all like what she had hoped for. A lot of the abuses might not even be mentioned because of lack of evidence. Then comes the main hearing and, very often, a minimum penalty. With good conduct the perpetrator can be released after serving two-thirds of his time. And if he has been in remand for a long time, he might be released shortly after the pronouncement of the judgement. This causes tremendous fear. A pending release from prison can provoke panic in a survivor. It is like a hand reaching out from behind and grabbing her by the neck, pulling her down into the same abyss she has just escaped from.

FIZ: And all the while she tries to build a new life for herself ...

Sara: Yes, she has to work on many sites at the same time. Many women also have to rediscover their relationship with their families. Some of them were hiding from the family, because they were forced into sex work by their relatives and exploited by them. But for most survivors to establish contact with their families is part of the process of healing and regaining their strength. It can be very painful. I remember encounters with mothers who were worth their weight in gold. They had travelled from far and stood firmly by their daughters. Other encounters ended in the opposite. The process of reunification is difficult. Sometimes it does not succeed at all.

Then there are women with children. They have to deal with their role as a mother. Often it is difficult for them to understand the needs of their children. The authorities in Switzerland monitor closely how they deal with the children. Often these women don't know what the authorities expect and fear that their child will be

1 This interview was first published in German in Fachstelle Frauenhandel und Frauenmigration, Das Leben nach der Ausbeutung, Rundbrief 57, November 2015, p. 8, retrieved 1 December 2017, https://www.fizinfo.ch/images/content/FIZ\%20Downloads_Deutsch/Downloads_Publikationen/Magazin\%20und\%20Rundbriefe/R undbriefe/Rundbrief\%2057:\%20Das\%20Leben\%20nach\%20der\%20Ausbeutung.pdf. 
taken from them. Some of them live in mother-and-child institutions and try very hard to meet expectations. But they still often don't succeed, because they don't understand what the authorities perceive as the child's welfare. The mothers have never received the care in their lives which they are expected to give their children.

FIZ: New social and maybe love relations also belong to a new life. How do survivors manage?

Sara: Many are ashamed for having worked in the sex industry. They ask themselves: 'How can I establish new contacts when I cannot tell anyone what I lived through and what I had to do?' Some women withdraw completely, because they are afraid of disapproval. Many live in constant fear that their story will be revealed and that they will lose everything.

Sometimes survivors have somewhat blurred boundaries. They put up with insults and often find themselves in relationships where they suffer again from violence. Survivors often have a huge yearning for belonging to someone and to be special to someone. And therefore they ignore warning signs.

FIZ: What other construction sites are there?

Sara: Work, education, a place to live. Many of our clients—but not all!have missed out on many years of school, not least because of the trafficking. This continues to hurt them years later. Starting school, finding work or traineeship in Switzerland is difficult for them. There are so many legal requirements that only a few can manage to enrol in a school or to find work. Many survivors have a very strong wish to find a job, but they have never learnt to work nine-to-five, to bear responsibilities or to meet commitments.

And then, while the psyche has managed to repress certain things, the body comes forward often when women have to function at work. Headaches, back and joints pain, colds. Their bodies can be the hand that grabs them by the neck and pulls them down.

FIZ: What is important in the process of counselling survivors?

Sara: It is very important to translate long-term aims into small steps. When a woman wants to work, it doesn't make sense just to send in applications. A first step could be an integration programme where she can learn the necessary skills she needs in order to find and keep a job. As a counsellor, I have to listen carefully: what are the wishes and goals of the client? And I have to weigh carefully: what is the realistic next step? If this step is too big, it can produce disappointment. It is important to start with small steps, to evaluate them and only then plan the next ones.

FIZ: Are there good experiences in counselling?

Sara: I admire my clients tremendously. After having survived terrible things, they go on and don't give up on their dreams. They try to give their children what they never got themselves. Many keep a sense of humour, warmth and caring for others. This is very impressive and yes-definitely a good experience!

FIZ Advocacy and Support for Migrant Women and Victims of Trafficking advocates for the protection and rights of migrant women in Switzerland. To this end, the organisation runs the Counselling Center for Migrant Women and the more specialised Makasi - Counselling and Support Services for Victims of Trafficking in Women. FIZ also works in the areas of education and policy. Email: contact@fiz-info.ch 